\title{
ОБ ЭФФЕКТИВНОСТИ ОБРАБОТКИ СЕМЕННЫХ КЛУБНЕЙ КАРТОФЕЛЯ ЭТИЛЕНОМ
}

\author{
С.В. МАЛЬЦЕВ $\bowtie$
}

Картофель (Solanum tuberosum L.) - одна из важнейших сельскохозяйственных культур в России. Клубни картофеля содержат белок, отличающийся высокой биологической ценностью, крахмал и необходимые для человека витамины. Известны различные способы повышения урожайности этой культуры, центральное место среди которых в настоящее время занимает внесение минеральных удобрений. Однако этот способ имеет свои ограничения, поскольку увеличение фона питания сопряжено с ухудшением потребительских и кулинарных показателей клубней. Одна из возможных альтернатив - газация семенных клубней этиленом. Этот фитогормон широко применяется на различных культурах, но его влияние на картофель пока до конца не изучено. Известно, что в зависимости от режимов обработки он может выступать в качестве как стимулятора, так и ингибитора прорастания клубней. Нами разработан новый способ повышения урожайности картофеля, основанный на свойстве фитогормона этилена подавлять апикальное доминирование в начале прорастания клубней и тем самым способствовать формированию болышего числа боковых ростков, из которых образуются дополнительные стебли. Цель исследований - определить влияние обработки семенных клубней картофеля этиленом на их биохимические показатели, а также на рост, развитие и урожайность культуры. Опыты проводили на базе хранилищ АО «Озеры» (Озерский р-н, Московская обл.). Газацию осуществляли по адаптированной технологии фирмы «Restrain Company Ltd» (Великобритания). Температура хранения семенного картофеля составляла $4{ }^{\circ} \mathrm{C}$, срок газации этиленом - с ноября по конец апреля. Подачу этилена прекращали за 3-5 сут до посадки. Обработанный этиленом картофель высаживали в 2015-2017 годах на территории Московской области. Двухфакторный полевой опыт проводили в Люберецком районе на экспериментальной базе «Коренево». Опыт мелкоделяночный, почва - дерново-подзолистая супесчаная. Семенные клубни картофеля сортов зарубежной селекции Lady Claire (ранний), Gala (среднеранний) и Saturna (среднепоздний) обрабатывали этиленом. В контроле обработку не проводили. Трехфакторный опыт закладывали в Озерском районе при крупнотоварном производстве картофеля на базе хозяйства АО «Озеры». Почва - дерново-подзолистая суглинистая; общая площадь опыта 40 га. Использовали те же сорта и обработку, что и в первом опыте, а также учитывали орошение посевов. Проводили 2-3 полива по $200 \mathrm{~m}^{3} /$ га. В обоих опытах картофель высаживали в I декаде мая. Густота посадки 45 тыс. клубней/га, ширина междурядий 75 см, фон минерального питания N60Р120К120 при локальном внесении удобрений. Определяли биохимические и биометрические показатели, а также урожайность картофеля. Было установлено, что обработка семенных клубней этиленом при $4{ }^{\circ} \mathrm{C}$ вызывала изменение их биохимических показателей (содержание сухого вещества снижалось на 0,2-0,5\%, сахарозы - повышалось на 0,03-0,08 \%), что свидетельствовало о выходе клубней из состояния естественного покоя. Происходило подавление апикального доминирования и формирование большего числа боковых ростков на клубнях, образовывалось большее число стеблей на куст (на 19,9-36,0 \%), увеличивалось число клубней на куст (на 6,3-19,0 \%, в особенности у сорта Gala). Урожайность картофеля возрастала на 9,9-19,0 \% в зависимости от сорта, района выращивания и орошения. Также была отмечена более однородная структура урожая. В зависимости от уровня культуры земледелия и применяемой в хозяйстве агротехники предложен дифференцированный подход в выборе нормы высева семян: при низкой агротехнике и отсутствии орошения норму высева обработанных этиленом клубней в расчете на ту же урожайность можно снизить на 10-15\%.

Ключевые слова: картофель, сорт, этилен, фитогормон, фенологические фазы, число стеблей, урожайность, структура урожая, технология Restrain.

Фитогормон этилен может выступать и как стимулятор, и как ингибитор прорастания картофеля. Стимулирующие свойства этилена, которые обусловливают выход клубней из состояния естественного покоя, известны с 1925 года (1), а в 1932-1933 годах были выявлены его ингибирующие свойства $(2,3)$. В работе I. Rylski с соавт. (4) был показан двойной эффект этилена. Его кратковременное воздействие (72 ч в диапазоне 0,02-20 ppm) стимулировало начало прорастания клубней, а непрерывное действие при длительном хранении картофеля подавляло развитие ростков. Имеются сведения (5-8), что этилен способствует увеличению числа ростков, но при этом 
препятствует их росту в длину (элонгации).

Восприятие этилена начинается с его связывания с рецепторами, локализованными у всех высших растений в мембране эндоплазматического ретикулума и аппарата Гольджи (9). Необычная внутриклеточная локализация рецепторов не препятствует восприятию гормона, поскольку газообразный этилен свободно диффундирует в липидной и водной среде $(10,11)$. Предполагается, что связывание этилена с рецепторными гистидинкиназами изменяет их конформацию, инактивирует комплексы рецепторов с CTR1 (Cep/Tpe-протеинкиназа, подобная протеинкиназам Raf-семейства). Это приводит к дефосфорилированию белка EIN2, подобного металл-ионному транспортеру Nramp, и отщеплению его C-концевого домена, который переносится в ядро и инициирует транскрипционный ответ этилен-зависимых генов за счет последовательной активации факторов транскрипции семейств EIN3/EIL1 и ERF (12). Известно, что при непрерывном продолжительном пребывании в среде этилена в клубнях меняется соотношение полиаминов, участвующих в регуляции деления и роста клеток $(13,14)$. Такие изменения сортоспецифичны и связаны с прорастанием картофеля $(15,16)$.

Ранее в качестве «этиленпродуцентов» использовали различные химические соединения, в первую очередь 2-хлорэтилфосфоновую кислоту, однако применительно к культуре картофеля более технологичны другие системы подачи этилена $(17,18)$.

В настоящее время системы управления этиленом при хранении картофеля поставляют две британские компании. Обе используют одни и те же нормативы разрешенных концентраций этилена - до 50 мл/м ${ }^{3}$ (дозировка уточняется у производителя в зависимости от назначения картофеля). Одна из компаний («BioFresh Ltd») поставляет чистый этилен в баллонах (что потенциально взрывоопасно), концентрация газа в хранилище контролируется хемилюминесцентным датчиком. Другая компания («Restrain Company Ltd», в России представлена фирмой ООО «ПЕЯ Агро») производит систему, в которой этилен генерируется из этанола (19).

Существует множество приемов и способов, направленных на повышение урожайности картофеля, - использование безвирусных семян высоких репродукций, предпосадочная обработка клубней химическими и физическими методами, защита посадок от сорняков, болезней и вредителей, внесение удобрений, в первую очередь минеральных (20). Однако использование минеральных удобрений, даже при оптимальном соотношении NPK с учетом почвенно-климатических условий, часто приводит к снижению накопления в клубнях сухого вещества, крахмала, ухудшению потребительских (устойчивость мякоти к потемнению) и кулинарных показателей (вкус, рассыпчатость), вследствие чего снижается пригодность картофеля к переработке, например вакуумной упаковке и быстрой заморозке (21).

Мы разработали новый способ повышения урожайности картофеля, основанный на свойстве фитогормона этилена подавлять апикальное доминирование в начале прорастания клубней и тем самым способствовать формированию большего числа боковых ростков, из которых образуются дополнительные стебли.

Цель исследований - определить влияние обработки семенных клубней картофеля (Solanum tuberosum L.) этиленом на их биохимические показатели, а также на рост, развитие и урожайность культуры.

Методика. Опыты проводили на базе хранилищ АО «Озеры» (Озерский p-н, Московская обл.). Вместимость хранилищ составляла 2000 т. Газацию осуществляли по адаптированной технологии фирмы «Restrain 
Company Ltd.» (Великобритания). Адаптация технологии к российским условиям заключалась в том, что температура хранения семенного картофеля составляла не 6-8 ${ }^{\circ} \mathrm{C}$, как рекомендуется для климатических условий западных стран, а $4{ }^{\circ} \mathrm{C}$; срок газации этиленом был на 1 мес продолжительнее (с ноября по конец апреля, а не по конец марта). Поскольку зимы в Центральном регионе России более холодные и долгие, а посадка картофеля начинается на 1 мес позже, поддерживать повышенную температуру в хранилище было рискованно, так как в этом случае возможно преждевременное прорастание клубней. Для того чтобы клубни начинали прорастать своевременно, подачу этилена прекращали за 3-5 сут до посадки.

Обработанный этиленом картофель высаживали в 2015-2017 годах на территории Московской области. Двухфакторный полевой опыт (опыт 1; фактор А - сорт картофеля, фактор Б - обработка этиленом) проводили в Люберецком районе на экспериментальной базе «Коренево». Опыт мелкоделяночный, почва - дерново-подзолистая супесчаная. Семенные клубни картофеля сортов зарубежной селекции Lady Claire (ранний), Gala (среднеранний) и Saturna (среднепоздний) обрабатывали этиленом (газация в дозе 15 мл/м³; в контроле обработку не проводили). Повторность опыта 3-кратная.

Трехфакторный опыт (опыт 2; фактор А - сорт картофеля, фактор Б - обработка этиленом, фактор В - орошение) закладывали в Озерском районе при крупнотоварном производстве картофеля на базе хозяйства АО «Озеры». Почва - дерново-подзолистая суглинистая; общая площадь опыта 40 га. Сорта и варианты обработки почвы были теми же, что в опыте 1. Орошение посевов (первый вариант - контроль без орошения, второй вариант - 2-3 полива по $200 \mathrm{~m}^{3} /$ га) осуществляли с использованием дождевальных машин типа Фрегат (ПАО «Завод «Фрегат», Украина). В опыте было два варианта - с орошением и без. Повторность опыта 3-кратная.

В обоих опытах картофель высаживали в I декаде мая. Густота посадки 45 тыс. клубней/га, ширина междурядий 75 см, фон минерального питания $\mathrm{N}_{60} \mathrm{P}_{120} \mathrm{~K}_{120}$ при локальном внесении удобрений.

Биохимические (содержание сухого вещества, сахарозы, глюкозы, редуцирующих сахаров, нитратов, витамина С) и биометрические (число стеблей и клубней на куст) показатели, а также урожайность картофеля определяли по ГОСТ 29270-95 (22) и методике ФГБНУ ФИЦ картофеля им. А.Г. Лорха (23). Математическую обработку данных методом дисперсионного анализа проводили по Б.А. Доспехову (24) с использованием пакета программ AgCStat в виде надстройки к Microsoft Excel. Вычисляли среднее значение выборки $(M)$ и стандартное отклонение средней $( \pm \sigma)$. Значимость различий оценивали по $F$-критерию Фишера. При $F_{\text {факт. } \geq} F_{\text {теор. нулевая ги- }}$ потеза отвергалась (между выборочными средними есть существенные различия), и проверка заканчивалась расчетом наименьшей существенной разности для $5 \%$ уровня значимости (НСР05).

Результаты. Оборудование, использованное в эксперименте, представлено на рисунке 1. Обработка этиленом при длительном хранении семенных клубней приводила к изменению их биохимических показателей: количество сухого вещества снижалось на 0,2-0,5\% ( $\left.\mathrm{HCP}_{05} 0,3 \%\right)$, сахарозы - повышалось на $0,03-0,08 \%$, глюкозы - изменялось в пределах статистической погрешности (НСР05 $0,05 \%)$. Это свидетельствует о физиологическом влиянии этилена на выход клубней из состояния естественного покоя (25-27), сопровождающийся кратковременным ростом интенсивности дыхания, что согласуется с данными литературы (28-30). Содержание 
нитратов не превышало ПДК (90-100 мг/кг, НСР05 28 мг/кг). Количество витамина С зависело от сорта и срока хранения картофеля (19,7-29,0 мг\% при НСР05 1,3-1,5 мг\%), но не от применения этилена.
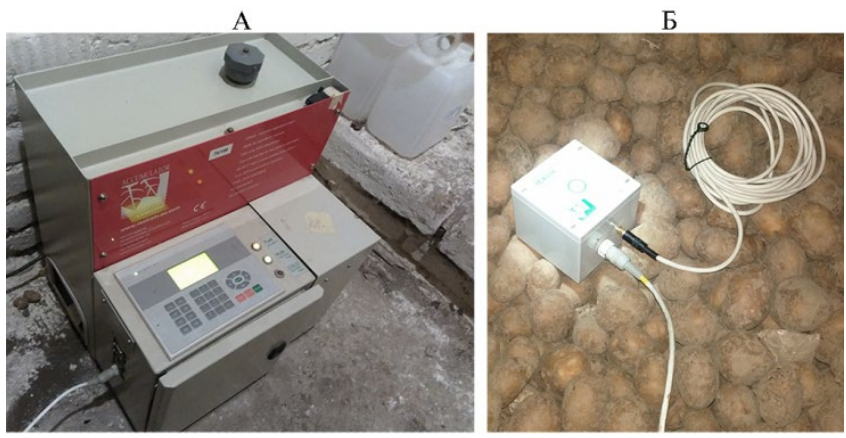

Рис. 1. Оборудование, использованное для обработки этиленом семенных клубней картофеля (Solanum tuberosum L.) сортов Lady Claire, Gala и Saturna: A - генератор этилена ACCUMULATOR («Restrain Company Ltd», Великобритания) (устанавливается в хранилище и при нагревании осуществляет каталитический распад 96 \% спирта этанола на этилен и воду), Б - датчик концентрации этилена ICA534 («Restrain Company Ltd», Великобритания), расположенный на поверхности насыпи картофеля, управляющий работой генератора.

Рост и развитие растений в полевых опытах в значительной степени определялись метеорологическими условиями вегетационного периода, особенно при выращивании в Люберецком районе Московской области, где орошение не применяли. Поэтому анализ эффективности использования этилена приводится в тесной взаимосвязи с метеоусловиями (табл. 1) отдельно по каждому году.

Как известно, недостаток влаги в фазу бутонизации-цветения не может быть компенсирован последующими осадками (критическая фаза развития). Дожди в мае и июне определяют число клубней картофеля, а дожди в июле и августе - массу клубней (31).

1. Краткая характеристика метеоусловий в период вегетации картофеля в районах проведения полевых опытов (Московская обл.)

\begin{tabular}{|c|c|c|c|c|c|c|c|c|c|c|c|c|}
\hline \multirow{2}{*}{ Район } & \multicolumn{4}{|c|}{2015 год } & \multicolumn{4}{|c|}{2016 год } & \multicolumn{4}{|c|}{2017 год } \\
\hline & май & ИЮНь & июль & август & май & ИЮНь & июль & август & май & ИЮНь & июль & август \\
\hline Люберецкий & ++ & + & - & - & ++ & - & ++ & ++ & + & + & ++ & ++ \\
\hline Озерский & ++ & + & ++ & - & ++ & ++ & + & ++ & + & + & ++ & ++ \\
\hline
\end{tabular}

Наименее благоприятным для роста и развития картофеля был 2015 год. В Люберецком районе в июле-августе наблюдалась засуха (см. табл. 1). В Озерском районе она наступила только в августе, поэтому за счет большей влагоудерживающей способности суглинистой почвы по сравнению с супесчаной растениям сортов Lady Claire, Gala и Saturna удалось накопить больший, чем в Люберецком районе, урожай - соответственно на $45 \%, 50 \%$ и $50 \%$, или на 7,6; 8,1 и 7,1 т/га. При двукратным поливе в Озерском районе в августе дефицит влаги был почти полностью компенсирован, что обеспечило прибавку урожая (без обработки клубней этиленом) в варианте с орошением по сравнению с вариантом без орошения соответственно на $27 \% ; 33$ \%; $21 \%$, или на 6,6; 7,9; 4,4 т/га. Кроме того, полив способствовал повышению выхода клубней товарной фракции (размером > 50 мм) на 4-5\%.

В 2015 году сорта картофеля, имеющие более продолжительный период созревания (Saturna, Gala), при выращивании без орошения в Люберецком районе оказались в менее выгодном положении по сравнению с раннеспелым сортом Lady Claire, который в большей степени успел реализовать биологический потенциал урожайности до наступления засухи. 
Обработка семенных клубней картофеля этиленом в 2015 году приводила к увеличению числа наклюнувшихся глазков (главным образом за счет боковых при исключении апикального доминирования) и появлению всходов на 3-5 сут раньше по сравнению с контролем. Растения были выше на 3-5 см и опережали контроль по площади листовой поверхности. Число стеблей на куст оказалось больше у сортов Lady Claire, Gala и Saturna соответственно на 20,0-22,4; 33,3-40,0 и 16,3-22,2 \%. Фаза начала клубнеобразования наступила на несколько суток раньше, и число клубней в пересчете на куст было больше - соответственно на 18,6-22,2; 23,531,9 и $11,8-19,1 \%$ (рис. 2).

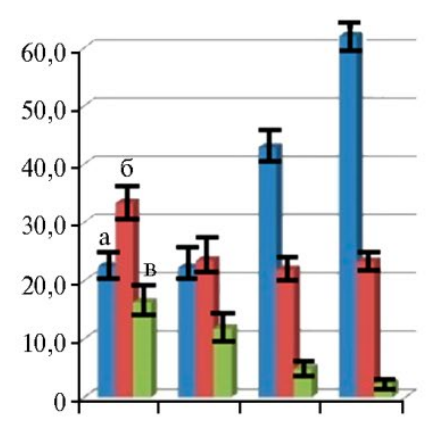

A
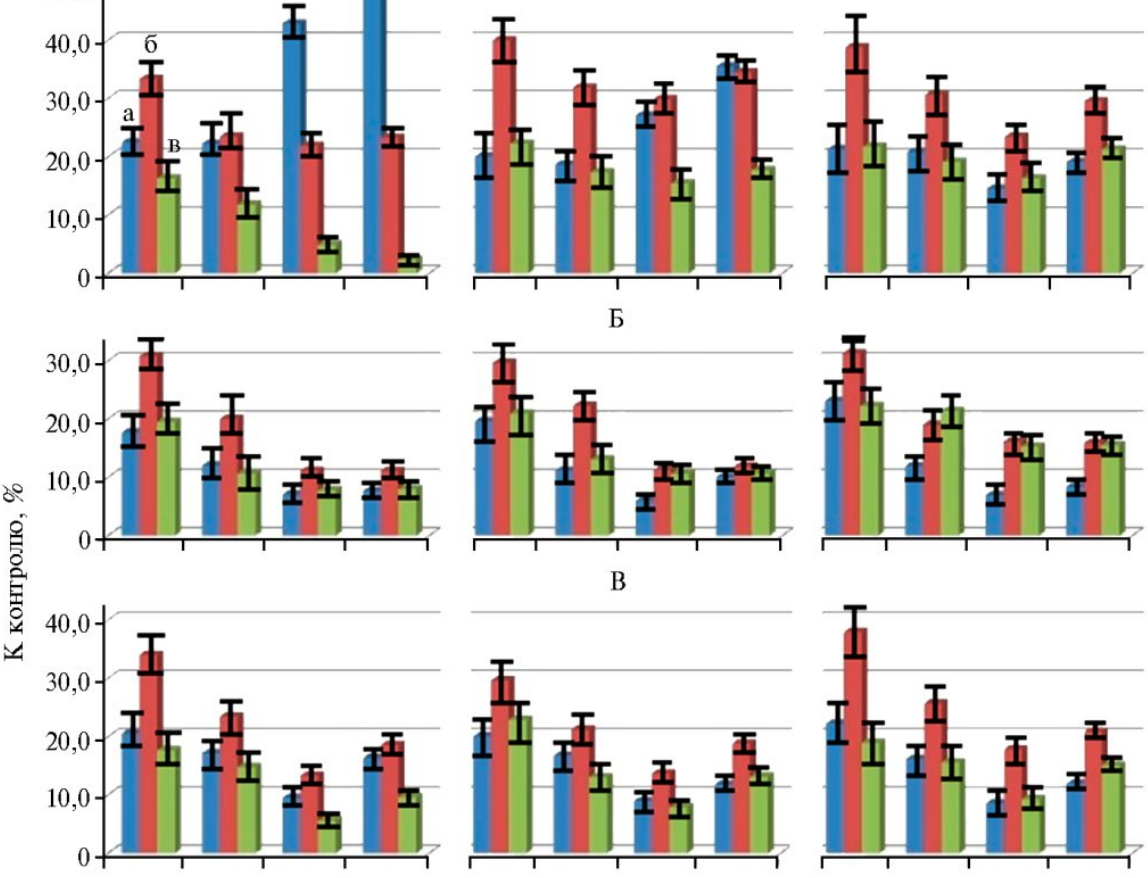

Б
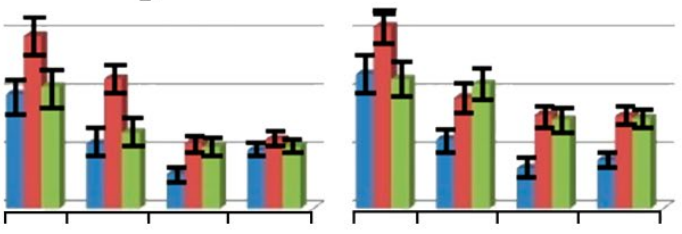

B
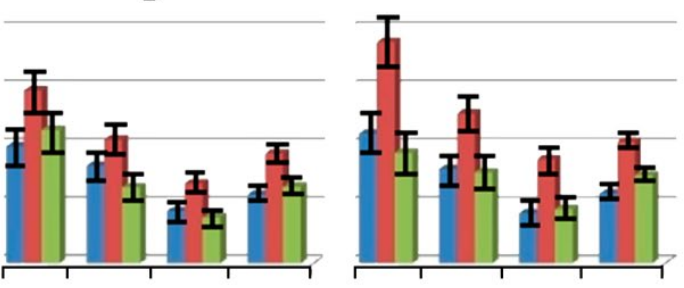

$\Gamma$
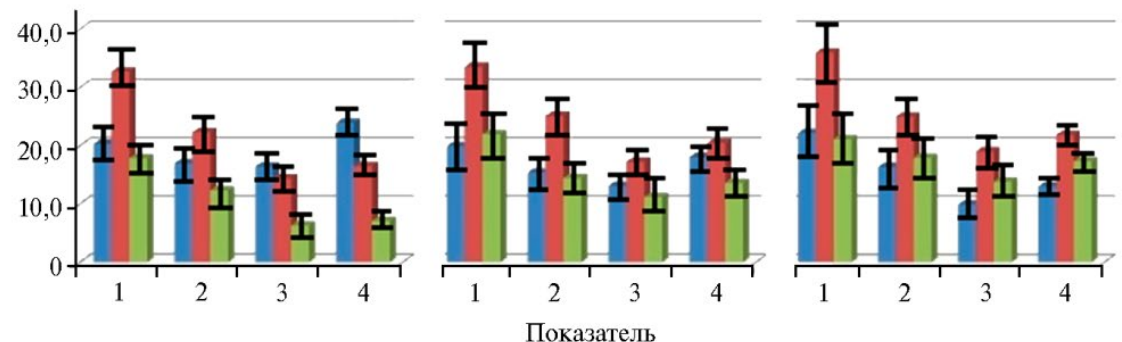

Рис. 2. Прирост показателей роста, развития и урожайности картофеля (Solanum tuberosum L.) сортов Lady Claire (a), Gala (б) и Saturna (в) при обработке семенных клубней этиленом в 2015 (А), 2016 (Б), 2017 (В) годах и в среднем за три года (Г): 1 - число стеблей, 2 - число клубней, 3 - общая урожайность, 4 - товарная урожайность; слева - Люберецкий район, супесчаная почва, без орошения, в центре - Озерский район, суглинистая почва, без орошения, справа Озерский район, суглинистая почва, с орошением ( $M \pm \sigma$; Московская обл.). Наблюдаемые различия с контролем статистически значимы при $\mathrm{p}<0,05$.

В конечном итоге урожайность в вариантах с обработкой семенных клубней этиленом в 2015 году по этим сортам возросла в зависимости от 
района выращивания и применения орошения соответственно на 14,5-42,9; 21,9-29,9 и 4,9-16,3 \%, или на 4,5-7,2; 3,5-7,5 и 0,7-4,2 т/га. Была отмечена также более однородная структура урожая (рис. 3).
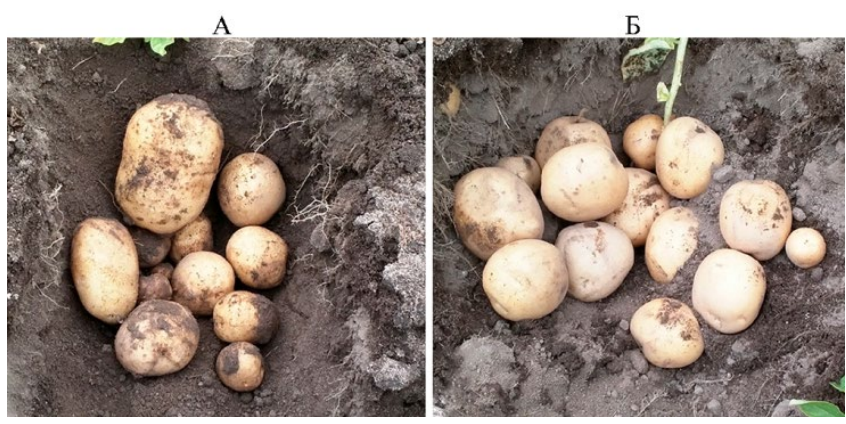

Рис. 3. Клубни картофеля (Solanum tuberosum L.) под кустом сорта Lady Claire при выращивании на дерново-подзолистой суглинистой почве: А - без обработки этиленом (контроль), Б с обработкой семенных клубней этиленом (Озерский р-н, Московская обл., 15 августа 2015 года). вием этилена на образование дополнительных клубней, но и смещением прохождения фенологических фаз развития на более ранние сроки, что было критически важно. Сорта более поздних групп спелости, особенно Saturna, в условиях с укороченным благоприятным вегетационным периодом оказались менее отзывчивы на обработку семенных клубней этиленом. В структуре их урожая доля мелкой фракции была увеличена, то есть преимущество в дополнительном клубнеобразовании реализовано не было.

2. Биометрические показатели и урожайность картофеля (Solanum tuberosum L.) разных сортов в контроле и при обработке семенных клубней этиленом в зависимости от района выращивания и применения орошения ( $M \pm \sigma$, Московская обл., 2015-2017 годы)

\begin{tabular}{|c|c|c|c|c|c|}
\hline \multirow{2}{*}{$\begin{array}{l}\text { Район выращивания } \\
\text { (почва) }\end{array}$} & \multirow{2}{*}{$\begin{array}{l}\text { Вариант хранения } \\
\text { и орошение }\end{array}$} & \multicolumn{2}{|c|}{ Число, шт/куст } & \multicolumn{2}{|c|}{ Урожайность, т/га } \\
\hline & & стеблей & клубней & общая & $\begin{array}{l}\text { товарная (клубни } \\
\text { фракции > } 50 \text { мм) }\end{array}$ \\
\hline \multicolumn{6}{|c|}{ Сорт Lady Claire (ранний) } \\
\hline Люберецкий & Контроль & $5,1 \pm 0,4$ & $10,0 \pm 0,6$ & $23,8 \pm 0,9$ & $18,9 \pm 0,7$ \\
\hline (супесчаная почва) & Этилен & $6,1 \pm 0,5$ & $11,7 \pm 0,7$ & $27,7 \pm 1,0$ & $23,5 \pm 0,8$ \\
\hline $\mathrm{HCP} 05$ & & 0,3 & 0,5 & 0,8 & 0,6 \\
\hline Озерский & Контроль (без орошения) & $5,2 \pm 0,4$ & $11,3 \pm 0,8$ & $28,3 \pm 1,4$ & $24,0 \pm 1,1$ \\
\hline \multirow[t]{3}{*}{ (суглинистая почва) } & Этилен (без орошения) & $6,2 \pm 0,6$ & $13,0 \pm 0,9$ & $32,0 \pm 1,5$ & $28,3 \pm 1,2$ \\
\hline & Контроль (с орошением) & $5,3 \pm 0,5$ & $12,3 \pm 0,7$ & $32,4 \pm 1,5$ & $28,8 \pm 1,2$ \\
\hline & Этилен (с орошением) & $6,4 \pm 0,6$ & $14,3 \pm 1,0$ & $35,6 \pm 1,6$ & $32,5 \pm 1,3$ \\
\hline \multirow[t]{2}{*}{$\mathrm{HCP}_{05}$} & & 0,4 & 0,7 & 1,2 & 1,0 \\
\hline & \multicolumn{3}{|c|}{ Cорт Gala (среднеранни й) } & & \\
\hline Люберецкий & Контроль & $5,4 \pm 0,5$ & $17,4 \pm 0,7$ & $23,9 \pm 1,0$ & $19,1 \pm 0,7$ \\
\hline (супесчаная почва) & Этилен & $7,2 \pm 0,6$ & $21,2 \pm 0,7$ & $27,3 \pm 1,1$ & $22,2 \pm 0,8$ \\
\hline $\mathrm{HCP} 05$ & & 0,3 & 0,6 & 0,8 & 0,6 \\
\hline Озерский & Контроль (без орошения) & $5,8 \pm 0,4$ & $18,3 \pm 1,0$ & $29,4 \pm 1,3$ & $25,3 \pm 1,1$ \\
\hline \multirow[t]{3}{*}{ (суглинистая почва) } & Этилен (без орошения) & $7,7 \pm 0,6$ & $22,9 \pm 1,1$ & $34,5 \pm 1,5$ & $30,5 \pm 1,2$ \\
\hline & Контроль (с орошением) & $6,3 \pm 0,6$ & $19,2 \pm 0,9$ & $33,9 \pm 1,4$ & $30,4 \pm 1,2$ \\
\hline & Этилен (с орошением) & $8,6 \pm 0,7$ & $24,0 \pm 1,0$ & $40,3 \pm 1,6$ & $37,0 \pm 1,4$ \\
\hline \multirow[t]{2}{*}{$\mathrm{HCP}_{05}$} & & 0,5 & 0,9 & 1,2 & 1,0 \\
\hline & \multicolumn{3}{|c|}{ Сорт Saturna (средне поздн и й) } & & \\
\hline Люберецкий & Контроль & $3,9 \pm 0,3$ & $9,8 \pm 0,5$ & $19,7 \pm 0,8$ & $14,6 \pm 0,6$ \\
\hline (супесчаная почва) & Этилен & $4,6 \pm 0,3$ & $11,0 \pm 0,6$ & $20,9 \pm 0,8$ & $15,7 \pm 0,6$ \\
\hline $\mathrm{HCP}_{05}$ & & 0,2 & 0,5 & 0,7 & 0,5 \\
\hline Озерский & Контроль (без орошения) & $4,1 \pm 0,4$ & $10,6 \pm 0,7$ & $23,3 \pm 1,1$ & $19,3 \pm 1,0$ \\
\hline \multirow{3}{*}{ (суглинистая почва) } & Этилен (без орошения) & $5,0 \pm 0,4$ & $12,2 \pm 0,8$ & $25,9 \pm 1,2$ & $22,0 \pm 1,1$ \\
\hline & Контроль (с орошением) & $4,3 \pm 0,4$ & $11,0 \pm 0,7$ & $26,4 \pm 1,4$ & $22,7 \pm 1,1$ \\
\hline & Этилен (с орошением) & $5,2 \pm 0,5$ & $13,0 \pm 0,8$ & $30,0 \pm 1,5$ & $26,7 \pm 1,3$ \\
\hline $\mathrm{HCP}_{05}$ & & 0,4 & 0,6 & 1,2 & 1,0 \\
\hline
\end{tabular}


Применение этилена на семенном картофеле в более благоприятные по влагообеспеченности 2016 и 2017 годы имело схожий эффект на прирост биометрических показателей и урожайности (см. рис. 2). В относительных значениях влияние этилена было заметно ниже, чем в 2015 году (по сортам Lady Claire, Gala и Saturna прирост урожайности составил соответственно $6,9-9,5 ; 11,1-17,8$ и 5,6-15,3 \% относительно контроля), однако в абсолютных значениях с учетом более высокой урожайности разницы по сравнению с 2015 годом почти не наблюдалось (соответственно 1,8-2,8; 3,1-6,2 и 1,24,5 т/га). Наиболее отзывчивым на применение этилена при благоприятных условиях выращивания и в среднем за 3 года оказался сорт Gala (табл. 2).

Схожие данные при использовании адаптированной к российским условиям технологии Restrain на семенном картофеле были получены в 2015-2016 годах в Дмитровском районе Московской области (32, 33). Использование оригинальной технологии Restrain при выращивании тех же сортов в Великобритании и Нидерландах в сочетании с более благоприятными климатическими условиями (влагообеспеченность в 2 раза выше) и при высокой культуре земледелия обеспечивало сопоставимые прибавки показателей роста и развития растений (+40 \% стеблей на куст; +20 \% клубней на куст) и увеличение общей урожайности до $20 \%$ (34).

Прирост урожайности картофеля при обработке этиленом в наших опытах не сопровождался снижением содержания в клубнях крахмала и сухого вещества, что часто бывает при внесении повышенных доз минеральных удобрений. В контроле эти показатели в среднем за 3 года составляли у сорта Lady Claire 17,5 и 23,2 \%, Gala - 16,4 и 22,0 \%, Saturna - 18,2 и 23,9 \%. При обработке семенных клубней этиленом значения были следующими: Lady Claire - 17,6 и 23,3 \%, Gala - 16,5 и 22,1 \%, Saturna - 18,1 и 23,8 \%. Содержание редуцирующих сахаров в послеуборочный период по изученным сортам вне зависимости от варианта обработки составило 0,15 $0,20 \%$. Не снижалась и устойчивость мякоти клубней к потемнению (8,08,5 баллов по 9-балльной шкале оценки как в контроле, так и в варианте с обработкой этиленом). В совокупности с достижением более однородной структуры урожая это крайне важно при выращивании картофеля для переработки на хрустящий картофель, производства быстрозамороженного картофеля (с учетом требований к форме клубней) и в вакуумной упаковке. При ранних сроках уборки появляется возможность получить более высокий урожай однородной семенной фракции картофеля.

Кроме того, обработка семенных клубней этиленом позволяет использовать дифференцированный подход в выборе нормы высева семян в зависимости от уровня культуры земледелия. При отсутствии орошения и низкой агротехнике норму высева можно снизить на 10-15\% в расчете на то, что применение этилена позволит добиться такого же стеблестоя на гектар и не меньшего урожая, чем при обычной норме высева, то есть можно сэкономить на семенном материале. При высоком уровне агротехники, наличии систем орошения и применении удобрений норму высева обработанных этиленом семян можно не снижать, поскольку растения картофеля будут способны реализовать весь свой биологический потенциал и накопить высокую урожайность.

Таким образом, обработка семенных клубней картофеля сортов Lady Claire, Gala и Saturna этиленом по адаптированной к российским условиям технологии Restrain способствовала изменению биохимических показателей клубней (содержание сухого вещества снижалось на 0,2-0,5 \%, количество 
сахарозы повышалось на 0,03-0,08 \%), подавлению апикального доминирования, образованию большего числа стеблей (на 19,9-36,0 \%) и клубней (на 6,3-19,0 \%) в пересчете на куст, формированию дополнительных боковых ростков и повышению урожайности на 9,9-19,0 \% в зависимости от сорта, района выращивания и применения орошения. Отмечена также более однородная структура урожая. Существенного влияния на содержание нитратов и витамина С в клубнях выявлено не было. Наиболее отзывчивым из изученных оказался среднеранний сорт Gala при орошении. В целом обработка семенных клубней фитогормоном этиленом позволяет увеличивать урожайность картофеля без использования повышенных доз минеральных удобрений, что исключает сопряженные с этим такие негативные последствия, как снижение содержания сухого вешества, крахмала и пригодности к переработке.

\section{Л ИТ Е РАТ УРА}

1. Rosa J.T. Shortening the rest period of potatoes with ethylene gas. Potato Association of America. Potato News Bulletin, 1925, 2: 363-365.

2. Elmer O.H. Growth Inhibition of potato sprouts by the volatile products of apples. Science, 1932, 75(1937): 193 (doi: 10.1126/science.75.1937.193).

3. Huelin F.E., Barker J. The effect of ethylene on the respiration and carbohydrate metabolism of potatoes. New Phytologist, 1939, 38(2): 85-104 (doi: 10.1111/J.14698137.1939.TB07087.X).

4. Rylski I., Rappaport L., Pratt H.K. Dual effects of ethylene on potato dormancy and sprout growth. Plant Physiology, 1974, 53(4): 658-662 (doi: 10.1104/pp.53.4.658).

5. Wills R.B.H., Warton M.A., Kim J.K. Effect of low levels of ethylene on sprouting of potatoes in storage. HortScience, 2004, 39(1): 136-137 (doi: 10.21273/HORTSCI.39.1.136).

6. Prange R.K., Daniels-Lake B.J., Pruski K. Effects of continuous ethylene treatment on potato tubers: highlights of 14 years of research. Acta Hortic., 2005, 684: 165-170 (doi: 10.17660/ActaHortic.2005.684.22).

7. Kalt W., Prange R.K., Daniels-Lake B.J., Walsh J.R., Dean P., Coffin R. Alternative compounds for the maintenance of processing quality of stored potatoes (Solanum tuberosum). Journal of Food Processing Preservation, 1999, 23(1): 71-81 (doi: 10.1111/j.1745-4549.1999.tb00370.x).

8. Martínez-Romero D., Bailén G., Serrano M., Guillen F., Valverde J.M., Zapata P., Castillo S., Valero D. Tools to maintain postharvest fruit and vegetable quality through the inhibition of ethylene action: a review. Critical Reviews in Food Science and Nutrition, 2007, 47(6): 543-560 (doi: 10.1080/10408390600846390).

9. Dong C.-H., Rivarola M., Resnick J.S., Maggin B.D., Chang C. Subcellular colocalization of Arabidopsis RTE1 and ETR1 supports a regulatory role for RTE1 in ETR1 ethylene signaling. The Plant Journal, 2008, 53(2): 275-286 (10.1111/j.1365313X.2007.03339.x).

10. Ju C., Chang C. Advances in ethylene signaling: protein complexes at the endoplasmatic reticulum membrane. AoB PLANTS, 2012, 2012: pls031 (doi: 10.1093/aobpla/pls031).

11. Lacey R.F., Binder B.M. How plants sense ethylene gas - the ethylene receptors. Journal of Inorganic Biochemistry, 2014, 133: 58-62 (doi: 10.1016/j.jinorgbio.2014.01.006).

12. Grierson D. 100 years of ethylene - a personal view. In: Annual Plant Reviews, vol. 44: The Plant Hormone Ethylene /M.T. McManus (ed.). Blackwell Publishing Ltd., 2012: 1-17 (doi: 10.1002/9781118223086.ch1).

13. Jeong J.-C., Prange R.K., Daniels-Lake B.J. Long-term exposure to ethylene affects polyamine levels and sprout development in 'Russet Burbank' and 'Shepody' potatoes. Journal of the American Society for Horticultural Science, 2002, 127(1): 122-126 (doi: 10.21273/JASHS.127.1.122).

14. Kaur-Sawhney R., Shih L.M., Flores H.E., Galston A.W. Relation of polyamine synthesis and titer to aging and senescence in oat leaves. Plant Physiology, 1982, 69: 405410 (doi: $10.1104 /$ pp.69.2.405). 
15. Daniels-Lake B.J., Prange R.K., Nowak J., Asiedu S.K., Walsh J.R. Sprout development and processing quality changes in potato tubers stored under ethylene: 1 . Effects of ethylene concentration. American Journal of Potato Research, 2005, 82: 389-397 (doi: 10.1007/BF02871969).

16. Knee M., Proctor F.J., Dover C.J. The technology of ethylene control: Use and removal in post-harvest handling of horticultural commodities. Annals of Applied Biology, 1985, 107(3): 581-595 (doi: 10.1111/j.1744-7348.1985.tb03174.x).

17. Creech D.L., Workman M., Harrison M.D. The influence of storage factors on endogenous ethylene production by potato tubers. American Potato Journal, 1973, 50: 145-150 (doi: 10.1007/BF02853204).

18. Землянская Е.В., Омельянчук Н.А., Ермаков А.А., Миронова В.В. Механизмы регуляции передачи этиленового сигнала у растений. Вавиловский журнал генетики и селекции, 2016, 20(3): 386-395 (doi: 10.18699/VJ15.105).

19. Lin Z., Zhong S., Grierson D. Recent advances in ethylene research. Journal of Experimental Botany, 2009, 60(12): 3311-3336 (doi: 10.1093/jxb/erp204).

20. Пшеченков К.А., Зейрук В.Н., Еланский С.Н., Мальцев С.В., Прямов С.Б. Хранение картофеля. М., 2016.

21. Мальцев С.В., Пшеченков К.А., Зейрук В.Н. Влияние химических и физических методов воздействия на клубни картофеля различного назначения при хранении. Мат. Межд. науч.-практ. конф. «Радиационные технологии в сельском хозяйстве и пищевой промышленности: состояние и перспективы». Обнинск, 2018: 285-289.

22. Доспехов Б.А. Методика полевого опыта (с основами статистической обработки результатов исследований). М., 1985.

23. Пшеченков К.А., Давыденкова О.Н., Седова В.И., Мальцев С.В., Чулков Б.А. Методические указания по оценке сортов картофеля на пригодность к переработке и хранению. М., 2008.

24. ГОСТ 29270-95. Продукты переработки плодов и овощей. Методы определения нитратов. М., 1995.

25. Reid M.S., Pratt H.K. Effects of ethylene on potato tuber respiration. Plant Physiology, 1972, 49(2): 252-255 (doi: 10.1104/pp.49.2.252).

26. Paul V., Ezekiel R., Pandey R. Sprout suppression on potato: need to look beyond CIPC for more effective and safer alternatives. Journal of Food and Science Technology, 2016, 53(1): 1-18 (doi: 10.1007/s13197-015-1980-3).

27. Saltveit M.E. Effect of ethylene on quality of fresh fruits and vegetables. Postharvest Biology and Technology, 1999, 15(3): 279-292 (doi: 10.1016/S0925-5214(98)00091-X).

28. Barry C.S., Giovannoni, J.J. Ethylene and fruit ripening. Journal of Plant Growth Regulation, 2007, 26: 143 (doi: 10.1007/s00344-007-9002-y).

29. Schaller G.E. Ethylene and the regulation of plant development. BMC Biology, 2012, 10: 9 (doi: 10.1186/1741-7007-10-9).

30. Vandenbusshe F., Vaseva I., Vissenberg K., Van Der Straeten D. Ethylene in vegetative development: a tale with a riddle. New Phytologist, 2012, 194(4): 895-909 (doi: 10.1111/j.1469-8137.2012.04100.x).

31. Лорх А.Г. Динамика накопления урожая картофеля. М., 1948.

32. Равич Д. Хранение картофеля и лука. Технология Restrain: современно, экологично, выгодно. Картофельная система, 2016, 3: 10-11.

33. Лищенко О.В., Щеглова И.А., Лищенко В.В. Состояние и перспективы развития продовольственной системы России: на примере картофельного комплекса. М., 2016.

34. Равич Д. Технология Restrain: азбука хранения. Картофельная система, 2018, 3: $10-11$.

ФГБНУ ФИЦ картофеля им. А.Г. Лорха, 140051 Россия, Московская обл., Люберецкий р-н, п. Красково, ул. Лорха, 23, литера «В»,

Поступила в редакцию

e-mail: stanmalcev@yandex.ru $₫$ 12 июля 2019 года

Sel'skokhozyaistvennaya biologiya [Agricultural Biology], 2021, V. 56, № 1, pp. 44-53

\section{EFFICIENCY OF ETHYLENE APPLICATION}




\title{
ON SEED POTATO TUBERS
}

\author{
S.V. Maltsev $\bowtie$
}

Lorkha Russian Potato Research Centre, 23-B, ul. Lorkha, pos. Korenevo, Lyuberetsky District, Moscow Province, 140051 Russia, e-mail stanmalcev@yandex.ru ( $₫$ corresponding author) ORCID:

Maltsev S.V. orcid.org/0000-0001-7211-315X

The author declares no conflict of interests

Received July 12, 2019

doi: 10.15389 /agrobiology.2021.1.44eng

\section{Abstract}

Potato (Solanum tuberosum L.) is one of the most important agricultural crops in Russia. Potato tubers contain protein of high biological value, starch and vitamins necessary for humans. There are various ways to increase the yield of the crop, currently, it is mainly due to application of mineral fertilizers. However, this method has limitations, since an increase in doses of fertilizers is associated with deterioration of consumer quality and culinary indicators of tubers. One possible alternative is the gassing of seed tubers with ethylene. This phytohormone is widely used on various crops, but its effect on potatoes has not yet been fully studied. It is known that depending on the treatment modes it can act as both a stimulator and an inhibitor of tuber germination. We have developed a new method for increasing potato yield based on the property of phytohormone ethylene to suppress apical dominance at the beginning of tuber germination and thereby promote the formation of a larger number of lateral sprouts from which additional stems are formed. The aim of the research was to determine the effect of seed potato tubers treatment with ethylene on their biochemical parameters, as well as on the growth, development and tuber yield of the crop. The experiments were conducted on the basis of storage facilities of JSC Ozyory (Ozyorsky District, Moscow Province). For gassing, the adapted technology of the company «Restrain Company Ltd» (Great Britain) was used. The storage temperature for seed potatoes was $4{ }^{\circ} \mathrm{C}$; the period of ethylene gassing was from November to the end of April. The treatment with ethylene was stopped 3-5 days before planting. Ethylene-treated potatoes were planted in 2015-2017 on the territory of the Moscow region. A two-factor small-plot field trial was conducted in the Lyuberetsky District at the Korenevo experimental base, the soil was sod-podzolic sandy loam. Seed tubers of potato varieties Lady Claire (early), Gala (mid-early) and Saturna (midlate) were treated with ethylene. In the control, ethylene was not applied. A three-factor large-scale (40 ha) field trial was performed during commercial potato growing of the same varieties (JSC Ozyory, Ozyorsky District, Moscow Province, sod-podzolic loamy soil). We used the same treatment as in experiment 1 added with 2-3 irrigation $\left(200 \mathrm{~m}^{3} / \mathrm{ha}\right)$. In both experiments, the potatoes were planted in the first decade of May (45 thousand tubers per hectare, row spacing width of $75 \mathrm{~cm}$; N60 $\mathrm{P} 120 \mathrm{~K} 120$ applied locally). Biochemical, biometric parameters, and potato yield were measured. It was found that the treatment of potato seed tubers with ethylene at $4{ }^{\circ} \mathrm{C}$ changes their biochemical parameters, i.e., dry matter content decreases by $0.2-0.5 \%$ while sucrose increases by $0.03-0.08 \%$, which indicates the breakdown of tubers' dormancy. There was a suppression of apical dominance and the formation of more lateral sprouts on tubers, a greater number of stems per plant (by 19.9-36.0\%), and an increase in number of tubers per plant (by 6.3-19.0\%, especially in the Gala variety). Potato yield increased by 9.9-19.0\% depending on the variety, growing area and irrigation. The produced potato tubers were more uniform and marketable. Depending on the common agricultural level and the technology used at a farm, a differentiated approach is proposed in choosing the planting rate. If low agricultural technology and no irrigation, the planting rate of ethylene-treated tubers reduced by $10-15 \%$ allows for the same yield as that for high technology and irrigation.

Keywords: potato, variety, ethylene, phytohormone, phenological phases, number of stems, yield, crop structure, Restrain technology. 